\title{
Interface between Subalternity and Sexuality in Arundhati Roy's The God of Small Things
}

\author{
Sedunath Dhakal ${ }^{1}$
}

\begin{abstract}
There is an interface between subalternity and sexuality in Arundhati Roy's 'The God of Small Things'. This article attempts to describe that sexuality has been stood as a form of protest and resistance against all forms of discrimination and prejudices against subaltern groups. The central characters of the novel, Velutha, and Ammu's copulation with each other is implicitly an attempt to break the artificial and arbitrary walls constructed between the so called elite class and the subaltern groups. Thus, the sexuality can be discussed as a means of liberation from the chain of subalternity. However, the attempt was averted when the protesters (Velutha and Ammu) confront the mechanical society. The act of copulation exposed the subalternity of Velutha and sexuality of Ammu. Both Ammu and Velutha cross the social boundary. So called marriage system and love laws both have been transgressed upon. It is due to the sexual act, the so called authentic laws and systems have been broken, all things dismissed, impossible become possible. Such instinct is uncontrollable. This article analyses that in the matter of sex, so called touchable and untouchable, master and servant, so called higher class and lower caste all become equal; there remains no boundary at all; as it has been presented in Arundhati Roy's The God of Small Things.
\end{abstract}

Key words: interface, subalternity, sexuality, resistance, caste discrimination, untouchability

\section{Concept of Subalternity}

Subaltern is a term first adopted by Antonio Gramsci to refer to those groups in society who are subject to the hegemony of the ruling classes. It includes peasants, workers and other groups ignored access to 'hegemonic' power. He used the term to describe the variety of different dominated and exploited groups in the society who explicitly lack

1 Mr. Dhakal is a lecturer of English at Koteshwor Multiple Campus, Koteshwor, Kathmandu affiliated to T.U. He is also the Head of English Department of this Campus. 
class consciousness. Gramsci categorized 'subaltern' in place of 'proletariat' who are by any way exploited and dominated by 'elite' group in the society; elite class rules the society by constructing the truth in their favours.

In a patriarchal male dominated society female are subaltern, lower class peopleuntouchable are subaltern in caste practices, politically inferior group who are underprivileged are subaltern in political system and practices. Since they are marginalized group of the society who are always dominated and discriminated in the society, they try to rebel against such discrimination. But it's not easy for them to rebel because of the power network constructed to suppress them. Rangit Guha (2002), in his essay The Prose of Counter-Insurgency, says:

... to rebel was indeed to destroy many of those familiar signs which he had learned to read and manipulate in order to extract a meaning up of the harsh world around him and live with it. The risk in turning things upside down under these conditions was indeed so great that he could hardly afford to engage in such a project in a state of absent-mindedness (Guha, 2002).

Subaltern people are effaced in the society because they cannot revolt and uplift their status. Their voices are under shadow. Their history is fragmented and episodic. They are subject to the ruling class. If the subaltern people try to get freedom they will be victimized because it will be against the rules and system of the elite group who creates the truth and discourse to suppress the so-called inferior. Gayatri Chakraverty Spivak (1994) one of the prominent subaltern writers has opined in her famous essay "Can the Subaltern Speak? (1994)" that the subaltern cannot revolt. They are speechless and unpicturable in the society. They don't have their own history. They are deviated from the mainstream culture too. Their history is ruptured by the colonizers. She further says: ". . . in the context of colonial production, the subaltern has no history and cannot speak" (Spivak, 1994).

But Sumit Sakar opines that the term is ambiguous because it doesn't have stable identity. As it is a heterogeneous term, it cannot be denoted to a particular group in the society. It does not have single criterion to identify as a subaltern. In The Conditions and Nature of Subaltern Militancy: Bengal from Swadeshi to Non-cooperation, Sakar (1984) writes: 
... subaltern is no more free of ambiguities and problems than its rough equivalents (for example 'popular mass', 'lower-class' ); it does have the advantage however of emphasizing the fundamental relationship of power, of domination and emphasizing the fundamental relationship of power, of domination and subaltern. Nor does the subaltern concept exclude more rigorous class-analysis where the subject or material permits it (Sarkar 1984).

\section{Subalternity and Sexuality in The God of Small Things}

Roy's The God of Small Things deals with the theme of subalternity and sexuality, and in the interplay of the two, the author makes her character violate the so called norms of the society. This is in turn leads the character to a tragic end. Ammu and Velutha's sexual relationship in the novel is the manifestation of subaltern resistance as the narrator says; "They all broke the rules. They all crossed into forbidden territory. They all tempered with the laws that lay down who should be loved and how. And how much" (Roy, 2002).

In the novel Ammu, the principal character, is doubly subalternized. On the one hand, due to her unsuccessful marriage, she is discriminated in male dominated society, and, on the other hand, she is socially segregated due to her relationship with an untouchable family carpenter, Velutha. Velutha is well-capable of handling respected job; yet he is not respected due to his untouchable caste. He is paid less because he is untouchable. The narrator says, 'Mammachy often said that if only he hadn't been a Paravan, he might have been an engineer' (Roy, 2002). He is neglected; he is just a small thing for them. 'Mammachy paid Velutha less than she would a touchable carpenter but more than she would a Paraven. Mammachy didn't encourage him to enter the house' (Roy 2002).

When her family and society find Velutha and Ammu close to each other, Ammu becomes outcaste; Velutha is beaten to death with the help of police. The sexual relation is a daring task in such society which breaks the live laws; 'The laws that lay down who should be loved. And how. And how much' (Roy 2002). It is, thus, a rebellion against love laws. The sexual relation between Velutha and Ammu is the cause of their fall. They tried to transgress the established trend of the society. The whole novel is the story of an increasingly dysfunctional family whose all members broke the rules in various ways, and crossed into forbidden territory. 
Sexual intercourse and the plight caused after it is the main subject matter of the plot of the The God of Small Things. Each family member has bitter experiences of unrequited love and sex. When Ammu's family and society find Velutha and Ammu close to each other, Ammu becomes outcaste; Velutha is beaten to death with the help of police. The sexual relation is a daring task in such society which breaks the love laws; "The laws that lay down who should be loved. And how much" (Roy 2003). It is, thus, a rebellion against love laws. The sexual relation between Velutha and Ammu is the cause of their fall, the fall of subaltern people. They tried to transgress the established trend of the society.

Indian family prefers arranged marriage; love marriage and sexual intercourse with lower caste man or woman are not religiously and socially accepted. The task of Ammu has problematized the Ayemenem family. She has had love marriage and is a divorcee. After that she started having relation with an untouchable family carpenter, which is even unbearable in the society. She is expelled from her parental home, because her need was just a small thing, 'they struck to the small things' (Roy 2002). But, big things happened after accident. Ammu was outcaste; Estha, her son, was returned to her ex-husband breaking the unbreakable friendship; and Rahel, her daughter, was let to Ayemenem house to be hated and neglected. Velutha, with whom she indulged in sexual and spiritual love affairs, was beaten to death by the police.

Arundhati Roy, thus, presenting the story of Indian subaltern groups, provides the glimpse to sexual indulgence. The natural sexual instinct emerged in such a way that no rules, laws and system of the society can protect. It creates violence at the end of the novel. She is punished because she develops an illicit sexual relationship with a Paravan. But Mr. Hollick, an Englishman and the employer of Ammu's husband, makes several illicit sexual relationships but he is highly respected in the society:

Mr. Hollick proposed that Baba go away for a while. For a holidays to a clinic perhaps, for treatment. For as along as it took him to get better. And for a period of time that he was away, Mr. Hollick suggested that Ammu be sent to be 'looked after'.

Already there were a number of ragged light skinned children on the estate that Hollick had bequeathed on the tea-pickers whom he fancied. This was his incursion into management circle. (Roy, 2002) 
But nobody would believe that an Englishman can fall into such behavior. Even Papachi, Ammu's father, would not believe it; 'Papachi would not believe her story-not because he thought well of her husband, but simply because he didn't believe that an Englishman, any Englishman, would covet another man's wife' (Roy 2002).

Sexual relationship between Ammu and Velutha in The God of Small Things is a resisting tool against the elite group. It is due to the sexual intercourse the subalternity has been exposed. Ammu discovers that it is sexuality which is a means of gratifying the baser desires where all the forms of distinctions are just nothing. Velutha's subalternity has also been exposed as he is finally beaten to death due to his contact with Ammu. They both cross the social boundary, marriage system and love laws. It is due to the sexual act of such subaltern people, the authentic laws and system has been broken, all things dismissed, impossible has become possible. Such instinct guided by 'Id' is uncontrollable. In the matter of sex touchable and untouchable, master and servant, higher caste and lower caste all are equal; there is no boundary. The same things take place in The God of Small Things.

The novel deals with the plight of subaltern people. Both Velutha and Ammu are the victim of subalternity. Ammu, with her twin son and daughter is left by her Bengali drunkard husband and compelled to sustain her life in maternal house where she is extremely hate $\mathrm{d}$ not only by her family but also by the society. She dies having no company with her at last. The narrator commenting about her death says; "She died alone. With a noisy ceiling fan for company and no Estha to lie at the back of her and talk to her" (Roy, 2002). This incident also shows that the common people in the society are dying like animals. It's just a simple death, what else! There will be nobody to care and mourn for those who die.

In the novel Ammu is exploited and dominated in the society on two ways: on the one hand, she is victimized in a patriarchal society due to her identity as a divorcee. She is socially segregated because she is husbandless after marriage and living in maternal house. To live in parent's house permanently after marriage is not positively accepted in the society. On the other hand, she is supposed to be an outcaste when her sexual relationship with Velutha is known to all. Talking about her position in society, the narrator in the novel further tells;

... a married daughter had no position in her parents' home. As for 
a divorced daughter -according to Baby Kochamma, she had no position anywhere at all. And as for a divorce daughter from a love marriage, well, words could not describe Baby Kochamma's outrage. As for a divorced daughter from an intercommunity love marriage- Baby Kochamma chose to remain quiveringly silent on the subject. (Roy 2002)

As depicted in the novel, the patriarchal society is biased and prejudiced which never accepts the female empowerment wholeheartedly. Women are not supposed to get education and opportunity. Talking about female education, the narrator tells; "Papachi insisted that a college education was an unnecessary expense for a girl, so Ammu had no choice but to leave Delhi and move with them" (Roy 2003). Early marriage is common to be free from the burden of education for girls; there was very little for a young girl to do in Ayemenem other than to wait for marriage proposals while she helped her mother with housework" (Roy, 2003)

Velutha, an untouchable family carpenter is socially hated because of his lower social rank and status. Although he did have capability and skills, he was not regarded and accepted as a useful skilled member of the society. Mamachi used to say about him, "if only he hadn't been Paravan, he might have become engineer" (Roy, 75). Lower class people have been segregated from holding good profession although they might have skills and ability. They are supposed to do the lower status jobs and activities like cleaning the toilets, serving the rich people, and other manual works. They are not allowed to establish any types of relationship with so-called higher class women. Velutha is beaten to death due to his relation with Ammu, an upper caste widow. So, Velutha's untouchable social position has finally turned into tragic consequences due to the physical relationship with Ammu. People even could not imagine the bodily contact and sexual relationship between so called untouchable family carpenter and so called touchable upper caste women.

The perspective to look at the sexual relationship is totally different in the society. Illicit relations of an Englishman is not considered as crime but if such is done by a simple Indian, then the society thinks he/she is finished, fallen down, an outcaste etc. This novel begins and ends with subalternity of Velutha and Ammu and their sexual indulgence that causes death at the end. Velutha's untouchable caste and Ammu's sexual 
relation with Velutha both are equally important for the downfall of both of them. It is an interface of the attempt of self discoveries between subalternity and sexuality. One affects another. Subalternity is explicitly exposed due to sexual intercourse between Velutha and Ammu.

Roy depicts the issues of womanhood and untouchability in this novel. These both are the basic identities of subalternity. The novel begins and ends within the periphery of these two identities of subalternity. It is an attempt to self-discovery of creating subalternity through sexuality as rebellion and protest against the existing norms and values.

\section{Conclusion}

Arundhati Roy's The God of Small Things deals with the theme of subalternity and sexuality, and in the interplay of the two, the author makes her characters violet the so called norms of the society. This in turn leads to a tragic end. Ammu and Velutha's sexual relationship as described in the novel is the manifestation of subaltern resistance. The main character, Ammu's Revillion against the social values is a direct resistance over the socio-cultural discourses set by the Indian society. This is, thus the story of forbidden cross-caste love affair ad sex, and what a community will do to protect the so-called moral norms and cultural systems. Sexuality is a form of resisting tool against the so-called elite group. It is due to the sexual intercourse the subalternity has been exposed. Ammu herself discovers that it is sexuality which is a means of gratifying the baser desires where all the forms of distinctions are just nothing. Velutha's subalternity has also been exposed as he is finally beaten to death due to his contact with Ammu. Both crossed the forbidden territory. Because of sexuality, the subalternity has been exposed and finally, the tragic consequences occurred.. 


\section{References}

Ashcroft, Bill. et. El. (1995). The Post Colonial Studies Reader. New York: Routledge.

Guha, Ranajit (2002). Subaltern Studies Reader. ed. Delhi: EOU.

Guha, Ranajit (1988). Dominance without Hegemony and its Historiography. Subaltern Studies VI. ed. Ranjit Guha. Delhi: Oxford University Press. (P.209-330)

Roy, Arundhati (2002). The God of Small Things. India: Penguin Books.

Sakar, Sumit (1984). The Conditions and Nature of Subaltern Militancy: Bengali from Swadeshi to Non-cooperation. Subaltern Studies III. ed. Ranajit Guha. Delhi: Oxford University Press.

Spivak, Gayatri Chakraverty (1994). Can The Subaltern Speak? Colonial Discourse and Post Colonial Studies: A Reader. ed. Patrick Williams and Laura Chrismass. New York: Columbia University Press ( P.66-111).

Spivak, Gayatri Chakraverty (1986). Subaltern Studies: Deconstructing Historiography. Subaltern Studies IV.ed. Ranajit Guha. Delhi: Oxford University Press. (P.330-363) 